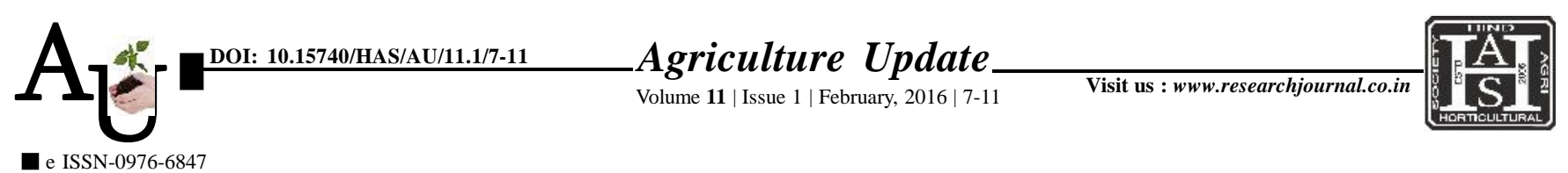

\title{
Research автіcle: Constraints faced by banana growers in adoption of banana production technology
}

\author{
SUJATA R. PAWAR, P.S. KAPSE AND R.D. AHIRE
}

Article Chronicle: Received :

09.12.2015;

Revised :

17.12.2015;

Accepted :

03.01.2016

KeY Words:

Constraints,

Suggestions,

Banana

production

technology

SUMMARY : The present study was conducted in Nanded district of Marathwada region of Maharashtra State with an objective to study the constraints faced by banana growers in adoption of banana production technology and obtained their suggestions to overcome these constraints. The data were collected with the help of interview schedule. The result of the study depicted that majority of the banana growers faced the constraints of load shedding of electricity during irrigation, followed by non-availability of suckers at the time of planting, high cost of wages for preparatory tillage operations, high cost of FYM or compost and chemical fertilizers and poor quality of suckers for planting. The data regarding suggestions of the respondents given to overcome the constraints faced by them in adoption of banana production technology revealed that information regarding irrigation should be given in time by extension agencies, followed by tissue culture plants should be made available in sufficient quantity, government should provide NADEP and vermicompost unit and pesticide should be provided at low cost, message alerts through SMS about insect, pest and control measures should be given to farmers in time, good quality sucker should be supplied to farmers in time and reducing the cost of fertilizer were the major suggestions.

How to cite this article : Pawar, Sujata R., Kapse, P. S. and Ahire, R.D. (2016). Constraints faced by banana growers in adoption of banana production technology. Agric. Update, 11(1): 7-11.

Author for correspondence :

\section{P.S. KAPSE}

Department of

Extension Education,

College of Agriculture,

Vasantrao Naik

Marathwada Krishi

Vidyapeeth, PARBHANI

(M.S.) INDIA

Email: pravinkapse@

rediffmail.com

See end of the article for

authors' affiliations 